\title{
Strategi Komunikasi Pemasaran Dinas Pariwisata, Kebudayaan, Pemuda Dan Olahraga Dalam Upaya Mengembangkan Pariwisata \\ Di Kabupaten Situbondo
}

\author{
Suyono HS*Faisal Adhim Bahriansyah Putra** \\ *Fisipol Unmuh Jember \\ **Alumnus Fisipol Unmuh Jember \\ Abstrak
}

\begin{abstract}
Skripsi ini mengkaji tentang Strategi Komunikasi Pemasaran Dinas Pariwisata, Kebudayaan, Pemuda dan Olahraga yang menarik untuk diteliti, karena pada saat ini Kabupaten Situbondo kaya akan keberagaman potensi wisata. Akan tetapi, Dinas Pariwisata, Kebudayaan, Pemuda dan Olahraga belum mampu memaksimalkan peran penting dalam pengembangan objek wisata yang dimiliki. Sehingga penelitian ini bertujuan untuk mengetahui dan mendeskripsikan strategi komunikasi pemasaran dan hambatan Dinas Pariwisata, Kebudayaan, Pemuda dan Olahraga dalam upaya mengembangkan pariwisata di Kabupaten Situbondo. Penelitian dilakukan di lokasi Dinas Pariwisata, Kebudayaan, Pemuda dan Olahraga Kabupaten Situbondo. Adapun permasalahan dari penelitian ini adalah bagaimana strategi komunikasi pemasaran dan hambatan Dinas Pariwisata, Kebudayaan, Pemuda dan Olahraga dalam upaya mengembangkan pariwisata di Kabupaten Situbondo. Penelitian ini dilakukan dengan menggunakan metode deskriptif paradigma kualitatif melalui beberapa tahapan yaitu observasi pendahuluan, wawancara dan dokumentasi yang berkaitan dengan strategi komunikasi pemasaran Dinas Pariwisata, Kebudayaan, Pemuda dan Olahraga. Hasil penelitian menunjukkan bahwa penerapan strategi komunikasi pemasaran Dinas Pariwisata, Kebudayaan, Pemuda dan Olahraga dalam upaya mengembangkan sektor pariwisata dengan melakukan tahapan pendataan/inventarisasi, perencanaan, dan pelaksanaan. Selanjutnya hambatan yang ditemukan dalam proses penyusunan strategi pemasaran adalah minimnya komunikator, pesan, dan media serta sarana dan prasarana yang kurang memadai.
\end{abstract}

Kata Kunci: Komunikasi pariwisata Situbondo

\begin{abstract}
S
This thesis examines the Strategy of Marketing Communications Department of tourism, Culture, youth and sports that interest scrutinized, because at this moment the Situbondo city is rich in diversity of tourism potential. However, the Department of tourism, Culture, youth and sports has been not able to maximize the significant role in the development of tourist owned. So this research have purposes to find out and describe the Strategy of Marketing Communications and obstacles of tourism department, culture, youth and sports in an effort to develop the tourism in Situbondo city. This research carried out at the location of Tourism department, culture, youth and sport of Situbondo City. A problem of this research is how the strategies of marketing communication and obstacles of Tourism department, culture, youth and sports in an effort to develop tourism in Situbondo City. This research was conducted using descriptive of paradigmatic qualitative method through several stages, namely the preliminary observation, interview and documentation that relate to the strategy of Marketing Communications Department of tourism, Culture, youth and sports. The results of the reserms
\end{abstract}


showed that the implementation of the strategy of Marketing Communications Department of tourism, Culture, youth and sports in an effort to develop the tourism sector through logging/inventory stages, planning, and implementation. Furthermore the obstacles found in the process of preparing the strategy of marketing is a poor Communicator, message, and media as well as facilities and infrastructure inadequate.

Keywords: communication of Situbondo tourism

\section{Pendahuluan}

Pariwisata merupakan sebuah industri hiburan yang sangat dibutuhkan oleh setiap orang. Kebanyakan orang disibukkan dengan pekerjaan atau rutinitas sehari-hari yang monoton, menyebabkan timbulnya suatu kejenuhan. Oleh karena itu, manusia memerlukan suatu kegiatan yang bersifat menghibur. Kegiatan ini dapat membantu seseorang untuk memiliki waktu senggang yang dapat dijadikan sebagai sarana pemulihan kejernihan pikiran, agarterhindar dari tekanan kegiatan sehari-hariyang dapat menimbulkan kejenuhan bahkan gejala yang disebut stress. Salah satu kegiatan yang dapat dilakukan seseorang dalam mengisi waktu luangnya adalah dengan melakukan kegiatan pariwisata. Berwisata pada dasarnya adalah kebutuhan setiap individu untuk mendapatkan sesuatu yang diinginkan baik secara fisik maupun psikologis, dengan melakukan kegiatan yang menyenangkan dalam waktu luangnya. Saat ini wisata alam merupakan salah satu pilihan wisata yang paling banyak diminati oleh para wisatawan (Yoeti, 1985:237-238).

Kabupaten Situbondo sebagai salah satu kota yang terkenal dengan "kota santri" yang berada di Provinsi Jawa Timur memiliki beraneka ragam keunikan dan daya tarik ialah Dinas Pariwisata, Kebudayaan, Pemuda dan Olahraga (Disparbudpora) Kabupaten potensi sumber daya cukup besar, terutama sumber daya alam maupun sumber daya budaya yang banyak digemari oleh para wisatawan. Potensi sumber daya tersebut didukung dengan keadaan iklim tropis, dapat menambah peluang dan nilai plus bagi Kabupaten Situbondo untuk mengembangkan sektor pariwisata maupun kebudayaan yang dapat dikenal oleh masyarakat luas. Berdasarkan hal tersebut, pembangunan pariwisata dapat dijadikan salah satu alternatif bagi Pemerintah Kabupaten Situbondo untuk meningkatkan daya tarik wisatawan mengunjungi Kabupaten Situbondo.

Beberapa wisata alam telah banyak dikembangkan di "kota santri" ini, misalnya Pantai Pasir Putih dan Taman Nasional Baluran yang merupakan iconutama yang menjadi obyek wisata unggulan di Kabupaten Situbondo. Namun terdapat beberapa obyek wisata alam lain yang tidak kalah menariknya, salah satunya adalah Pantai Bama, Pantai Banongan, Pantai Tampora, Pantai Lempuyang, Pantai Merak, Air Terjun Talempong, Gunung Rengganis, Gunung Ringgit.

Pembangunan sektor pariwisata di Kabupaten Situbondo juga mendapatkan perhatian dari Pemerintah Kabupaten (Pemkab) Situbondo. Namun pada konteks tersebut, Pemkab Situbondo dalam hal ini

Situbondo yang khususnya melaksanakan tugas sebagai pengatur dan pengelola dalam bidang 
Pariwisata terlihat belum mampu memaksimalkan peran penting dalam pengembangan beberapa obyek wisata yang dimiliki. Buruknya pengelolaan wisata di Kabupaten Situbondo dapat dilihat dari keterbatasan dan kurangnya sarana dan prasarana di beberapa tempat wisata yang masih belum memadai dan tidak terawat. Hal ini tentu sangat berdampak besar pada citra tempat tujuan pariwisata.

Instansi tersebut juga dinilai belum mampu menciptakan strategi komunikasi pemasaran yang efektif, guna mempengaruhi masyarakat luas untuk tahu dan peduli akan keberadaan keragaman potensi obyek wisata yang dimiliki Kabupaten Situbondo. Hal tersebut dibuktikan dengan minimnya informasi dan pengetahuan masyarakat "kota santri" akan keberadaan ragam potensi wisata yang dimiliki Kabupaten Situbondo. Keadaan ini harus segera ditangani karena dinilai akan berpengaruh pada peningkatan kunjungan wisatawan sekaligus untuk menunjang kelancaran dan terlaksananya kegiatan pariwisata di Kabupaten Situbondo, agar tetap bisa mewujudkan obyek-obyek wisata unggulan yang mampu berdaya saing serta meningkatkan dan melestarikan pariwisata daerah. Oleh sebab itu, Disparbudpora Kabupaten Situbondo memiliki peran dan fungsi penting menggapai cita-cita dan tujuan untuk mengembangkan ragam potensi wisata yang dimilikinya.

Peneliti akan mengkaji permasalahan strategi komunikasi pemasaranDisparbudpora Manfaat
Kabupaten Situbondo sehubungan dengan promosi/penyebaran informasi dalam upaya mengembangkan ragam potensi wisata terhadap wisatawan. Hal itu dilakukan dengan asumsi bahwa upaya promosi dan pengembangan serta pelestarian haruslah sesuai dengan sudut pandang kearifan lokal.Adapun yang menjadi kata kunci dalam penelitian ini adalah Strategi Komunikasi Pemasaran Dinas Pariwisata, Kebudayaan, Pemuda dan Olahraga.

\section{Perumusan Masalah}

Berdasarkan latar belakang di atas, maka rumusan masalah dalam penelitian ini adalah:

1. Bagaimana strategi komunikasi pemasaran Dinas Pariwisata, Kebudayaan, Pemuda dan Olahraga dalam upayamengembangkan pariwisata di Kabupaten Situbondo ?

2. Apa saja hambatan yang dihadapi Dinas Pariwisata, Kebudayaan, Pemuda dan Olahraga dalam upaya mengembangkan pariwisata di Kabupaten Situbondo?

\section{Tujuan}

1. Mengetahui strategi komunikasi pemasaran Dinas Pariwisata, Kebudayaan, Pemuda dan Olahraga dalam upaya mengembangkan pariwisata di Kabupaten Situbondo.

2. Mengetahui hambatan yang dihadapi Dinas Pariwisata, Kebudayaan, Pemuda dan Olahraga dalam upaya mengembangkan pariwisata di Kabupaten Situbondo

1. Secara teoritis penelitian ini bermanfaat untuk pengembangan ilmu 
komunikasi terutama yang berkaitan dengan pembengan strategi pemasaran pariwisata.

2. Secara praktis penelitian ini berkugana untuk pengembangan strategi komunikasi untuk memasarkan obyek pariwisata di Kebupaten Situbondo, apalagi kabupaten tersebut terletak di jalur utara pantai pulau jawa

\section{Tinjauan Pustaka}

\section{Strategi Pemasaran}

\section{Konsep Strategi Pemasaran}

Strategi pemasaran merupakan suatu manajemen yang disusun untuk mempercepat pemecahan persoalan pemasaran dan membuat keputusan-keputusan yang bersifat strategis. Setiap fungsi manajemen memberikan kontribusi tertentu pada saat penyusunan strategi pada level yang berbeda. Pemasaran merupakan fungsi yang memiliki kontak paling besar dengan lingkungan eksternal, padahal perusahaan hanya memiliki kendali yang terbatas terhadap lingkungan eksternal. Oleh karena itu pemasaran memainkan peranan penting dalam pengembangan strategi.

Dalam peranan strategisnya, pemasaran mencakup setiap usaha untuk mencapai kesesuaian antara perusahaan dengan lingkungannya dalam rangka mencari pemecahan atas masalah penentuan dua pertimbangan pokok, yaitu (Tjiptono, 2008:6)

Bisnis ada yang digeluti perusahaan pada saat ini dan jenis bisnis apa yang dapat dimasuki di masa mendatang

a. Bagaimana bisnis yang telah dipilih tersebut e. langka atau pasar yang terproteksi. dapat dijalankan dengan sukses dalam lingkungan yang kompetitif atas dasar perspektif produk, harga promosi dan distribusi (bauran pemasaran) untuk melayani pasar sasaran.

Dalam konteks penyusunan strategi, pemasaran memiliki 2 dimensi yaitu dimensi saat ini dan dimensi yang akan datang. Dimensi saat ini berkaitan dengan hubungan yang telah ada antara perusahaan dengan lingkungannya. Sedangkan dimensi masa yang akan datang mencakup hubungan dimasa yang akan datang yang diharapkan akan dapat terjalin dan program tindakan yang diperlukan untuk mencapai tujuan tersebut.

Menurut Coray (Tjiptono, 2008:6-7) dalam strategi pemasaran terdiri atas lima elemen-elemen yang saling berkait. Kelima elemen tersebut adalah pemilihan pasar yaitu memilih pasar yang akan dilayani. Keputusan ini didasarkan pada faktor-faktor berikut ini.

1. Pemilihan pasar, yaitu memilih pasar yang akan dilayani. Keputusan ini didasarkan pada faktor:

a. Persepsi terhadap fungsi produk dan pengelompokan teknologi yang dapat diproteksi dan didominasi;

b. Keterbatasan sumbar daya internal yang mendorong perlunya pemusatan (fokus) yang sempit.

c. Pengalaman kumulatif yang didasarkan pada trial-aud-error di dalam menanggapi peluang dan tantangan.

d. Kemampuan khusus yang berasal dari akses terhadap sumber daya 
Pemilihan pasar dimulai dengan melakukan segmentasi pasar dan kemudian memilih pasar sasaran yang paling memungkinkan untuk dilayani oleh perusahaan;

2. Perencaan produk, meliputi spesifik yang terjual, pembentukan ini produk dan desain penawaran individual pada masing-masing ini. Produk itu sendiri menawarkan manfaat total yang dapat diperoleh pelanggan dengan melakukan pembelian. Manfaat tersebut meliputi produk itu sendiri, nama merek produk, ketersediaan produk, jaminan atau garansi, jasa reparasi dan bantuan teknis yang disediakan penjual, serta hubungan personal yang mungkin terbentuk diantara pembeli dan penjual;

3. Penetapan harga, yaitu menentukan harga yang dapat mencerminkan nilai kuantitatif dari produk kepada pelanggan;

4. Sistem distribusi, yaitu saluran perdagangan grosir dan eceran yang dilalui produk hingga mencapai konsumen akhir yang membeli dan menggunakannya;

5. Komunikasi pemasaran (promosi) yang meliputi periklanan, personal selling, promosi penjualan, direct marketing dan public relations.

Dalam merumuskan strategi pemasaran dibutuhkan pendekatan-pendekatan analistis. Pendekatan strategi pemasaran suatu perusahaan untuk menanggapi setiap perubahan kondisi pasar dan faktor biaya tergantung pada analisis terhadap faktor-faktor berikut ini: (Tjiptono, 2008:7)

a. Faktor lingkungan
Analisis terhadap faktor lingkungan seperti pertumbuhan populasi dan peraturan pemerintah sangat penting untuk mengetahui pangaruh yang ditimbulkannya pada bisnis perusahaan. Selain itu faktorfaktor seperti perkembangan teknologi, tingkat inflasi dan gaya hidup juga tidak boleh diabaikan. Hal-hal tersebut merupakan faktor lingkungan yang harus dipertimbangkan sesuai dengan produk dan pasar perusahaan;

b. Faktor pasar

Setiap perusahaan perlu selalu memperhatikan dan mempertimbangkan faktor-faktor seperti ukuran pasar, tingkat pertumbuhan, tahap perkembangan, trend dalam sistem distribusi, pola perilaku pembeli, permintaan musiman, segmen pasar yang ada saat ini atau yang dapat dikembangkan lagi, dan peluang-peluang yang belum terpenuhi.

c. Faktor persaingan

Dalam kaitannya dengan persaingan, setiap perusahaan perlu memahami siapa pesaingnya, bagaimana posisi prosuk/pasar pesaing tersebut, apa strategi mereka, kekuatan dan kelemahan pesaing, struktur biaya pesaing dan kapasitas produk pesaing.

d. Faktor analisis kemampuan internal

Setiap perusahaan perlu menilai kekuatan dan kelemahan dibandingkan para pesaingnya. Penilaian tersebut dapat didasarkan pada faktor-faktor seperti teknologi, sumber daya finansial, kemampuan pemanufakturan, kekuatan 
pemasaran dan basis pelanggan yang dimiliki.

e. Faktor perilaku konsumen

Perilaku konsumen perlu dipantau dan dianalisis karena hal ini sangat bermanfaat bagi pengembangan produk, desain produk, penetapan harga, pemilihan saluran distribusi dan penentuan strategi promosi. Analisis perilaku konsumen dapat dilakukan dengan penelitian (riset pasar) baik melalui observasi maupun metode survai.

f. Faktor analisi ekonomi

Dalam analisi ekonomi, perusahaan dapat memperkirakan pengaruh setiap peluang pemasaran terhadap kemungkinan mendapatkan laba. Analisis ekonomi terdiri atas analisis terhdapa komitmen yang diperlukan, analisis BEP (break even point)., penilaianm resiko/laba, dan analisis faktor ekonomi pesaing.

\section{Perencanaan Strategi Pemasaran}

Bagi komunikasi pemasaran, perencanaan strategis adalah proses mengidentifikasi problem yang dapat dipecahkan dengan komunikasi pemasaran kemudian menentukan tujuan/sasaran (apa yang ingin dicapai), menentukan strategi (bagaimana mencapai tujuan), dan mengimplementasikan taktik (aksi untuk menjalankan rencana). Proses ini terjadi di dalam kerangka waktu spesifik (Sandra, 2011:234).

Bahkan mereka yang berpengalaman di bidang periklanan terkadang kesulitan untuk membedakan antara tujuan dan strategi. Tujuan adalah sesuatu yang harus dicapai; dalam periklanan tujuan, ditentukan oleh efekyang ingin diraih. Strategi adalah alat, sarana, desain, atau rancangan untuk mencapai tujuan. Pesan periklanan dan strategi media misalnya; dalam periklanan, taktik adalah cara mengeksekusi iklan dan komunikasi pemasaran lainnya, bagaimana desain tersebut dan apa isi penyampaiannya.

Pada kasus Kodak, tujuannya adalah mereposisi brand untuk film ke foto. Strateginya adalah memfokuskan Kodak sebagai galeri, tempat dan sistem untuk menyimpan foto-foto favorit. Taktiknya antara lain membuat galeri EasyShare online yang dikaitkan dengan lini produk. Easyshare yang terdiri dari kamera baru, printer, aksesoris, software, dan kios yang secara keseluruhan menjadi sistem EasyShare.

Untuk memilah-milah perbedaan antara tujuan, strategi dan taktik, perhatikan situasi ini. Jika tujuan pemasar adalah memperkuat loyalitas brand untuk produknya, maka perencana dapat menggunakan beberapa strategi. Tujuan pada level pemasaran biasanya difokuskan pada sales dan pangsa pasar, yakni pengukuran persentase pembelian kategori produk oleh konsumen. Tujuan lainnya berkaitan dengan bauran pemasaran seperti distribusi, dimana tujuannya mungkin adalah mencoba membuka pasar baru.

Bagi manajer pemasaran, bagian paling penting dari rencana pemasaran adalah strategi bauran pemasaran. Ini menghubungkan semua rencana bisnis strategis dengan program pemasaran spesifik, seperti periklanan dan IMC. Kampanye periklanan atau strategi penjualan untuk 
menaikkan loyalitas brand adalah keputusan komunikasi pemasaran yang mendukung strategi pemasaran (Sandra, 2011:238).

\section{Metode penelitian}

Jenis penelitian ini adalah penelitian kualitatif. Menurut Denzin dan Lincoln (dalam Moleong, 2012:5), menyatakan bahwa penelitian kualitatif adalah penelitian yang menggunakan latar alamiah, dengan maksud menafsirkan fenomena yang terjadi dan dilakukan dengan jalan menguraikan dan mendeskripsikan. Lokasi penelitian dilaksanakan di kantor Dinas Pariwisata, Kebudayaan, Pemuda dan Olahraga Kabupaten Situbondo, Jalan PB. Sudirman No. 200, Telp. (0338) 676071. Hal ini dikarenakan instansi tersebut merupakan unsur pelaksana Pemerintah Kabupaten khususnya di bidang Pariwisata. Dinas Pariwisata, Kebudayaan, Pemuda dan Olahraga Kabupaten Situbondo dinilai belum maksimal dalam mengelola berbagai objek wisata. Metode yang digunakan untuk mengumpulkan data dalam penelitian ini adalah wawancara (interview), observasi, serta dokumentasi

Dalam penelitian ini teknik yang digunakan untuk mengumpulkan informan adalah teknik purposive sampling. Teknik ini digunakan peneliti untuk memudahkan proses pengambilan data dengan cara penentuan informan yang ditetapkan secara sengaja atas dasar kriteria atau pertimbangan tertentu. Pemilihan informan didasarkan pada kriteria dengan urutan sebagai berikut:

dan narna Pangeran Situborido atau Pangeran a. Pegawai Negeri Sipil (PNS) yang bekerja di Dinas Pariwisata, Kebudayaan, Pemuda dan Olahraga Kabupaten Situbondo;

b. Pegawai Negeri Sipil (PNS) yang relevan dalam bidangnya;

c. Pegawai negeri Sipil (PNS) yang ditunjuk oleh Dinas Pariwisata, Kebudayaan, Pemuda dan Olahraga Kabupaten Situbondo sebagai informan;

d. Pegawai Negeri Sipil (PNS) yang bersedia menjadi informan.

\section{Bahasan Kabupaten Situbondo}

Kabupaten Situbondo merupakan salah satu Kabupaten di Jawa Timur yang cukup dikenal dengan sebutan Daerah Wisata Pasir Putih yang terletak di posisi antara $7^{\circ} 35^{\prime}-7^{\circ}$ 44' Lintang Selatan dan $113^{\circ} 30^{\prime}-114^{\circ} 42^{\prime}$ Bujur Timur. Kabupaten Situbondo berbatasan dengan Selat Madura di sebelah utara, sebelah timur berbatasan dengan Selat Bali, sebelah selatan berbatasan dengan Kabupaten Bondowoso dan Banyuwangi, serta sebelah barat berbatasan dengan Kabupaten Probolinggo.

Luas wilayah Kabupaten Situbondo secara keseluruhan adalah $1.669,87 \mathrm{~km}^{2}$, dari luas daerah tersebut dihuni penduduk dengan jumlah 669.713 jiwa (keadaan pada tahun 2015). Dari data kependudukan yang diperoleh bahwa kepadatan penduduk di Kabupaten Situbondo dengan perbandingan 350 jiwa per $\mathrm{km}^{2}$. Bentuknya memanjang dari barat ke timur kurang lebih $140 \mathrm{~km}$ dan mempunyai rata-rata lebar wilayah kurang lebih $11 \mathrm{~km}$.

Berdasarkan Legenda Pangeran Situbondo, nama Kabupaten Situbondo berasal Aryo Gajah Situbondo, dimana sepengetahuan 
masyarakat Situbondo bahwa Pangeran Situbondo tidak pernah menampakkan dir. Hal tersebut dikarenakan keberadaannya di Kabupaten Situbondo kemungkinan sudah dalam keadaan meninggal-dunia akibat kekalahan pertarungannya dengan Joko Jumput, sehingga hanya ditandai dengan ditemukannya sebuah 'odheng' (ikat kepala) Pangeran Situbondo yang ditemukan di wilayah Kelurahan Patokan dan sekarang dijadikan Ibukota Kabupaten Situbondo. Sedangkan menurut pemeo yang berkembang di masyarakat, arti kata SITUBONDO berasal dan kata $:$ SITI $=$ tanah dan BONDO ikat. Hal tersebut dikaitkan dengan suatu keyakinan bahwa orang pendatang akan diikat untuk menetap di tanah Situbondo. Kenyataan mendekati kebenaran karena banyak orang pendatang yang akhirnya menetap di Kabupaten Situbondo.

Kota Situbondo secara umum tidak mempunyai penduduk asli, hampir semua penduduk Situbondo adalah pendatang hal ini disebabkan karena Kabupaten Situbondo adalah Kabupaten yang relatif masih muda dan merupakan daerah baru yang masih sedang berkembang. Para pendatang ini kebanyakan berasal dari pulau Madura dan sebagian lainnya berasal dari daerah yang memiliki budaya Jawa. Para pendatang ini kemudian berakulturasi satu dengan yang lainnya, baik dari segi adat kebiasaan, budaya ataupun bahasa. Walaupun secara dominan bahasa dan budaya yang dipakai di Kabupaten Situbondo adalah budaya dan bahasa Madura.

Sesuai dengan Staatsblad No. 322
Tahun 1929 Tanggal 1 Januari 1929, daerah Situbondo secara administratif menjadi Kabupaten. Berdasarkan Pasal 73 ayat 4 Undang-Undang No. 6 tahun 1973 Tentang Pokok-Pokok Pemerintahan di Daerah. Kabupaten Situbondo secara umum tidak mempunyai penduduk asli, hampir semua penduduk Situbondo adalah pendatang, hal ini disebabkan karena Kabupaten Situbondo adalah Kabupaten yang relatif masih muda dan merupakan daerah baru yang masih sedang berkembang. Para pendatang ini kebanyakan berasal dari pulau Madura dan sebagian lainnya berasal dari daerah yang memiliki budaya Jawa. Para pendatang ini kemudian berakulturasi satu dengan yang lainnya, baik dari segi adat kebiasaan, budaya ataupun bahasa. Walaupun secara dominan bahasa dan budaya yang dipakai di Kabupaten Situbondo adalah budaya dan bahasa Madura.

\section{Pembahasan}

\section{Strategi Komunikasi Pemasaran Dinas}

Pariwisata, Kebudayaan, Pemuda dan Olahraga

Berdasarkan salah satu penetapan pencapaian kinerja Dinas Pariwisata, Kebudayaan, Pemuda dan Olahraga Kabupaten Situbondo Tahun 2013 khususnya di bidang pariwisata, yaitu meningkatnya jumlah kunjungan wisata. Sasaran ini dicapai melalui beberapa program, sebagai berikut: (Laporan Akuntabilitas Instansi Pemerintah Dinas Pariwisata, Kebudayaan, Pemuda dan Olahraga Kabupaten Situbondo, 2013)

a. Pengembangan pemasaran pariwisata 
dengan kegiatan promosi pariwisata Nusantara di dalam dan luar daerah. Kegiatan promosi pariwisata tersebut diikuti oleh Dinas Pariwisata, Kebudayaan, Pemuda dan Olahraga Kabupaten Situbondo yang dilaksanakan di dua tempat di luar daerah, yaitu Makassar dan Bali.

b. Pengembangan destinasi pariwisata

1. Pengembangan jenis dan paket wisata unggulan

Pengembangan jenis dan paket wisata dikemas dalam kegiatan yang melibatkan masyarakat luas yaitu "Len Jelenan Sareng Bupati”. Kegiatan ini terdiri dari jalan sehat bersama Bupati, pameran kuliner khas Situbondo, ditutup dengan musik kontemporer yang mendatangkan artis Ibukota "D'Masive".

2. Pengembangan fasilitas olahraga maritim

Untuk lebih menarik wisatawan lokal maupun luar daerah, di Desa Bantal Kecamatan Asembagus ada waduk yang diberi bantuan fasilitas olahraga berupa Fun Rafting 'Samir Indah', yaitu perahu karet beserta kelengkapannya.

Strategi komunikasi pemasaran adalah suatu perencanaan dan manajemen untuk mencapai suatu tujuan yang ditetapkan. Sehubungan dengan hal tersebut, Dinas Pariwisata, Kebudayaan, Pemuda dan Olahraga Kabupaten Situbondo memiliki strategi komunikasi pemasaran dalam upaya mengembangkan pariwisata daerah. Adapun strategi komunikasi pemasaran tersebut adalah (1) meningkatkan kerja sama dan peran serta masyarakat/komunitas lokal, dunia usaha dan lembaga sosial kemasyarakatan dalam rangka peningkatan pengembangan pembangunan khususnya di bidang pariwisata. Peningkatan kerja sama dan peran dilakukan dengan koordinasi dan sinkronisasi dalam pelaksanaan kegiatan melalui skala prioritas program, dengan sasaran memelihara dan melestarikan keragaman kekayaan wisata daerah, menyediakan sarana dan prasarana, serta meningkatkan kunjungan wisata; (2) dalam meningkatkan koordinasi, konsultasi dan sinkronisasi dengan Instansi/Dinas terkait di tingkat Pemerintah, baik di tingkat Pemerintah Provinsi maupun di tingkat Pemerintah Daerah Kabupaten/Kota.

Dalam menyusun strategi komunikasi pemasaran, Disparbudpora tidak serta merta melakukan suatu penyusunan. Akan tetapi dibutuhkan suatu tahapan, yang mana tahapan tersebut sangatlah penting agar strategi komunikasi pemasaran tersebut dapat tersusun dengan baik. Adapun tahapan-tahapan strategi komunikasi pemasaran Disparbudpora yaitu:

1. Pendataan/inventarisasi Dinas Pariwisata, Kebudayaan, Pemuda dan Olahraga terhadap potensi wisata Kabupaten Situbondo.

Pada dasarnya proses pendataan/inventarisasi objek wisata yang dilakukan oleh Disparbudpora Kabupaten Situbondo tidak memiliki jadwal tertentu. Sehinggapendataan/inventarisasidapatdilak ukantanpamenentukanwaktu.Tidakmenutup kemungkinanpendataan/inventarisasijugada patdilakukandenganadanyainformasidarima syarakat luas. 
Mengenai

proses

pendataan/inventarisasi objek wisata yang dilakukan oleh Dinas Pariwisata, Kebudayaan, Pemuda dan Olahraga Kabupaten Situbondo, terekam dalam wawancara dengan Sugeng Hermanto, Amd, sebagai berikut:

"Disparbudpora telah melaksanakan inventarisasiasi potensi wisata yang dilaksanakan pada tahun 2009 melalui dana $A P B D$. Secara keseluruhan objek wisata telah diinventarisasiasi oleh Disparbudpora. Dengan keterbatasan pengetahuan mengenai potensi wisata yang ada di Kabupaten Situbondo tentunya Disparbudpora sejak dulu selalu membuka peluang dan juga bekerja sama dengan pihak kecamatan selaku pemilik daerah yang memang paham betul dengan kondisi daerah tersebut. Tidak menutup kemungkinan jika terdapat informasi dari pihak masyarakat mengenai adanya potensi wisata baru, Disparbudpora akan melaksanakan inventarisasiasi lagi untuk kedepannya. Akan tetapi hingga saat ini belum ada satupun dari pihak kecamatan maupun masyarakat yang menginformasikan keberadaan potensi wisata didaerahnya. Dari sekian banyak potensi wisata yang telah diinventarisasi, yang menjadi daya tarik Disparbudpora untuk dikembangkan lebih lanjut adalah Taman Nasional Baluran dan Pantai Tampora. Kedua objek wisata tersebut masuk dalam kategori pengembangan jangka panjang. Akan tetapi, Taman Nasional Baluran memang sudah cukup berkembang dan menjadi salah satu objek wisata unggulan. Hal tersebut terlihat pada meningkatnya jumlah kunjungan wisatawan pada setiap tahunnya. Hanya saja Taman Nasional Baluran tidak bisa dijadikan tourism massal, sebab Baluran adalah daerah konservasi sehingga ada keterbatasan untuk menambahkan sarana dan prasarana. Pantai Tampora juga sudah mulai banyak dikunjungi para wisatawan dan direkomendasikan untuk menjadi salah satu wisata unggulan untuk kedepannya karena lokasi yang strategis yaitu dipinggir jalan raya pantura dan akses menuju pantai tersebut terbilang sangat mudah, bahkan dari mereka juga ada yang camping di tepi pantai" (Wawancara: Rabu, 6 Mei 2015).

Disparbudpora melakukan suatu pendataan/inventarisasiasi pada potensi wisata secara menyeluruh. Dari sekian banyak potensi wisata yang telah diinventarisasi namun yang menjadi daya tarik Disparbudpora untuk dikembangkan lebih lanjut adalah Taman Nasional Baluran dan Pantai Tampora. Akan tetapi, Taman Nasional Baluran tidak sepenuhnya bisa dijadikan tourism massal, sebab pada dasarnya Baluran adalah daerah konservasi sehingga terdapat keterbatasan untuk menambahkan sarana dan prasarana demi menjaga ekosistem yang ada.

Pada sisi lain tidak menutup kemungkinan Disparbudpora maupun Duta Wisata selaku komunikator selalu membuka peluang dan bekerja sama dengan pihak kecamatan maupun masyarakat sebagai pemilik daerah yang mengetahui tentang kondisi daerah tersebut 
untuk memberi informasi mengenai adanya potensi wisata baru. Akan tetapi, pada kenyataannya tidak sebanding dengan pernyataan yang dinyatakan oleh pihak Disparbudpora. Hingga saat ini tidak terdapat satupun dari pihak kecamatan maupun masyarakat yang menginformasikan tentang keberadaan potensi wisata baru di daerah tersebut. Hal ini dikarenakan kurangnya pendekatan Disparbudpora maupun Duta Wisata selaku komunikator dalam menyampaikan pesan tentang potensi wisata baru.

2. Perencanaan Dinas Pariwisata, Kebudayaan, Pemuda dan Olahraga Kabupaten Situbondo.

Pada dasarnya proses penyusunan perencanaan sangat berpengaruh terhadap keberhasilan suatu strategi yang dilakukan oleh Disparbudpora. Dikarenakan suatu perencanaan merupakan langkah awal untuk mencapai tujuan yang terarah dan jelas, sehingga secara keseluruhan komponen dalam suatu instansi mengetahui dengan baik tujuan yang akan dicapai.

Dalam membuat suatu perencanaan Dinas Pariwisata, Kebudayaan, Pemuda dan Olahraga Kabupaten Situbondo juga berencana untuk berkoordinasi dengan Satuan Kerja Perangkat Daerah (SKPD) terkait, pihak Taman Nasional Baluran serta Duta Wisata terpilih yang akan ditunjuk selaku komunikator yang secara khusus menyampaikan/mengkomunikasikan

keanekaragaman keberadaan potensi wisata daerah melalui berbagai macam event. Hal ini dilakukan agar sektor pariwisata
Kabupaten Situbondo mulai dikenal dan mampu berdaya saing dengan wilayah lainnya.

Mengenai proses perencanaan objek wisata yang dilakukan oleh Dinas Pariwisata, Kebudayaan, Pemuda dan Olahraga Kabupaten Situbondo, terekam dalam wawancara dengan Drs. Partono Pranayoga, sebagai berikut:

"Cara Disparbudpora mengkomunikasikan bentuk perencanaan adalah berkoordinasi dengan pihak Taman Nasional Baluran, Duta Wisata terpilih serta SKPD yang lain untuk membuat berbagai macam event yang dilakukan satu tahun sebelum melakukan pelaksanaan. Langkah Disparbudpora dalam melakukan perencanaan yang maksimal bukan hanya terpaku pada wisata alam saja, tetapi acara kebudayaan bisa dikedepankan juga. Objek wisata yang menjadi sasaran utama dalam perencanaan pengembangan Disparbudpora tentunya adalah Taman Nasional Baluran, karena peningkatan jumlah kunjungan wisata dari tahun ke tahun selalu meningkat. Contohnya seperti beberapa waktu yang lalu penyanyi Ibukota tertarik melakukan shooting video clip di Taman Nasional Baluran. Hal ini tentunya sangat berpengaruh pada kunjungan wisatawan untuk kedepannya. Inovasi baru kami agar Situbondo bisa lebih dikenal oleh masyarakat luas khususnya di bidang pariwisata, untuk sementara ini kami hanya mempromosikan wisata Situbondo pertama dari meningkatkan fasilitas pengembangan sarana dan prasarana dalam jangka 
panjang, akan mengikutsertakan peran masyarakat, akan menyediakan laman website untuk memudahkan wisatawan dalam mengakses objek wisata mana yang akan dikunjungi, akan menyediakan Public Event yang disebarkan di beberapa sudut daerah di Kabupaten Situbondo guna memberi informasi kepada masyarakat, akan menunjuk perwakilan Duta Wisata terpilih untuk mengukuti ajang pemilihan Raka-Raki Jawa Timur dalam rangka pengenalan keanekaragaman potensi wisata Kabupaten Situbondo, akan bekerja sama minimal dengan salah satu pihak media televisi nasional, akan menyediakan brosur untuk disebarkan kepada berbagai biro perjalanan. Inovasi seperti ini baru dilakukan sekarang, dan sebelumnya tidak pernah melakukan inovasi sedemikian rupa. Kelebihan dari inovasi ini dinilai lebih efektif, karena secara otomatis dapat menginformasikan kepada semua yang menerima informasi tersebut dan bisa di akses oleh wisatawan lokal maupun wisatawan asing terutama melalui media yang tersedia" (Wawancara: Hari Kamis, 7 Mei 2015).

Langkah Disparbudpora dalam mengkomunikasikan bentuk perencanaan yang maksimal tidak hanya fokus pada wisata alam saja akan tetapi Disparbudpora juga mengutamakan berbagai macam event untuk mengenalkan sektor pariwisata Kabupaten Situbondo. Event tersebut akan dilaksanakan setelah perencanaan tersebut disusun. Sehingga hal tersebut dapat menambah informasi/wawasan kepada masyarakat/wisatawan untuk mengenal lebih dalam tentang kekayaan dan keberagaman potensi wisata yang dimiliki Kabupaten Situbondo.

Dari pernyataan diatas, Disparbudpora juga berencana untuk berkoordinasi dengan pihak Taman Nasional Baluran dalam melakukan perencanaan pembangunan sarana dan prasarana dalam jangka waktu yang panjang. Disparbudpora juga akan memberi informasi/pesan melalui media yang berupa laman website untuk memudahkan wisatawan dalam mengakses objek wisata mana yang akan dikunjungi, akan menyediakan Public Event yang disebarkan di beberapa sudut daerah di Kabupaten Situbondo guna memberi informasi yang efektif kepada masyarakat, akan bekerja sama minimal dengan salah satu pihak media televisi nasional, akan menyediakan brosur untuk disebarluaskan kepada berbagai biro perjalanan/travel, akan menunjuk perwakilan Duta Wisata terpilih sebagai salah satu komunikator untuk mengikuti ajang pemilihan Raka-Raki Jawa Timur dalam rangka promosi sekaligus mengenalkan keanekaragaman potensi wisata yang dimiliki Kabupaten Situbondo.

Namun dari sekian banyak perencanaan yang disusun oleh Disparbudpora, terdapat beberapa kekurangan yang belum terpecahkan dari tahun-tahun sebelumnya yaitu tidak transparan dalam melakukan penyusunan suatu perencanaan sehingga masyarakat tidak mengetahui bagaimana untuk ikut 
serta dalam melakukan penyusunan perencanaan. Hal tersebut sangat berpengaruh pada keberhasilan suatu instansi dalam menyusun perencanaan.

3. Pelaksanaan Dinas Pariwisata, Kebudayaan, Pemuda dan Olahraga Kabupaten Situbondo.

Pelaksanaan adalah suatu wujud dari perencanaan yang jauh sebelumnya telah dibuat. Tingkat keberhasilan suatu pelaksanaan dapat dilihat dari seberapa matang perencanaan tersebut. Pelaksanaan juga akan berjalan dengan baik apabila diimbangi dengan kerja sama antar instansi yang terkait maupun masyarakat dalam pengembangan kepariwisataan daerah.

Secara umum pelaksanaan strategi komunikasi pemasaran Disparbudpora adalah usaha-usaha yang dilakukan untuk melaksanakan semua rencana dan kebijaksanaan yang telah dirumuskan dan ditetapkan dengan melengkapi segala fasilitas sarana dan prasarana yang diperlukan, siapa saja komunikatornya, dimana tempat pelaksanaannya, kapan waktu dimulainya, dan media apa yang digunakan serta pengaruh media tersebut.

Mengenai proses pelaksanaan objek wisata yang dilakukan oleh Dinas Pariwisata, Kebudayaan, Pemuda dan Olahraga Kabupaten Situbondo, terekam dalam wawancara dengan Jupri Setyo Utomo, S.STP, sebagai berikut:

"Bentuk pelaksanaan strategi yang dilakukan Disparbudpora menyesuaikan pada perencanaan yang telah dibuat terlebih dahulu, contohnya dengan menjaga, melestarikan, serta meningkatkan fasilitas sarana dan prasarana demi kenyamanan wisatawan yang mengunjungi objek wisata yang dikembangkan, mengadakan berbagai macam event yang sebelumnya telah disusun seperti Festival Ancak Agung, Best Situbondo Carnival, Gerak Jalan Siput, dan beberapa event lain seperti yang tertera pada Public Event Kabupaten Situbondo. Disparbudpora juga telah menyediakan media sosial berupa laman website untuk mempermudah wisatawan dalam mengakses informasi tentang objek wisata mana yang akan dikunjungi, menyebar luaskan brosur kepada biro perjalanan/travel untuk memperkenalkan objek wisata yang sebelumnya tidak terdapat pada paket wisata. Selain itu kami juga bekerja sama dengan salah satu pihak media televisi swasta nasional yaitu MNC TV, kami mendatangkan mereka dan memilih beberapa tempat wisata yang sekiranya berpengaruh dalam menarik minat wisatawan untuk datang ke tempat tersebut khususnya tempat-tempat wisata tersembunyi agar terekspos oleh media dan dilihat khalayak, dan yang terakhir kami telah mengirim perwakilan Duta Wisata dalam ajang pemilihan Raka-Raki Jawa Timur untuk mewakili Kabupaten Situbondo dalam rangka promosi sekaligus mengenalkan keanekaragaman potensi wisata yang dimiliki Kabupaten Situbondo. Selain itu yang berperan penting dalam pelaksanaan strategi ini tetentunya dari semua pihak Disparbudpora yang didukung 
oleh pihak internal dan eksternal yaitu instansi yang terkait, masyarakat dan para seniman daerah, pihak sponsor, dan pihakpihak yang lain. Pelaksanaan tidak akan berjalan dengan lancar tanpa ada dukungan dari pihak luar. Hal ini terbukti dengan banyaknya pengunjung yang menyukai laman website, padahal kami baru menjalankan website tersebut sekitar kurang lebih tiga bulan" (Wawancara: Hari Kamis, 7 Mei 2015).

Dalam melaksanakan suatu strategi komunikasi pemasaran sebagai wujud dalam upaya mengembangkan sektor pariwisata daerah, Disparbudpora menyesuaikan pada perencanaan yang sebelumnya telah dibuat terlebih dahulu. Menjaga, melestarikan, serta meningkatkan fasilitas sarana dan prasarana demi kenyamanan wisatawan saat mengunjungi objek wisata yang dikembangkan, akan tetapi hingga saat ini Disparbudpora belum melakukan perbaikan jalan/akses menuju wisata Savana Bekol maupun Pantai Bama, tidak terlaksananya pembangunan atas rusaknya Mangrove Trail di Pantai Bama dan kurang mendapat perhatian khusus terhadap sarana dan prasarana Pantai Tampora oleh Disparbudpora seperti papan perhatian maupun pemberitahuan, toilet umum dan berbagai sarana lainnya.

Disparbudpora juga telah mengadakan berbagai macam kegiatan yang sebelumnya telah disusun dalam perencanan yang tertera pada Public Event Kabupaten Situbondo, telah menyediakan media sosial berupa laman website untuk mempermudah wisatawan dalam mengakses informasi tentang objek wisata manakah yang akan dikunjungi, telah menyebarluaskan brosur kepada biro perjalanan/travel untuk memperkenalkan objek wisata yang sebelumnya tidak terdapat pada paket wisata. Selain itu, Disparbudpora juga menjalin kerja sama dengan salah satu pihak media televisi swasta nasional yaitu MNC TV dalam rangka meliput beberapa potensi wisata yang berpengaruh dalam menarik minat wisatawan untuk datang ke objek tersebut khususnya objek wisata tersembunyi agar terekspos oleh media dan dilihat khalayak sekaligus mempromosikan/mengenalkan sektor pariwisata Kabupaten Situbondo. Pada kesempatan lain, Disparbudpora telah mengirim perwakilan Duta Wisata dalam ajang pemilihan Raka-Raki Jawa Timur untuk mewakili Kabupaten Situbondo sebagai komunikator dalam rangka promosi sekaligus mengenalkan keberagaman potensi wisata yang dimiliki Kabupaten Situbondo.

Selain itu yang berperan penting dalam pelaksanaan strategi ini tentunya dari semua pihak Disparbudpora yang didukung oleh pihak internal dan eksternal yaitu instansi yang terkait, masyarakat dan para seniman daerah, pihak sponsor pada setiap kegiatan, dan pihak-pihak yang lain. Pelaksanaan tidak akan berjalan dengan lancar tanpa ada dukungan dari pihak luar. Hal ini terbukti dengan banyaknya pengunjung yang mengunjungi sekaligus menyukai laman website. Akan tetapi pada 
kenyataannya keikutsertaan peran masyarakat dalam mengembangkan potensi wisata Kabupaten Situbondo dinilai masih kurang. Peran masyarakat untuk mengikuti berbagai kegiatan dalam upaya mengembangkan potensi wisata daerah hanya dilakukan oleh sebagian kecil. Sehingga perlunya perhatian khusus dari pihak Disparbudpora dalam menyampaikan pesan dengan melakukan suatu pendekatan kepada masyarakat untuk menjadikan strategi komunikasi pemasaran yang lebih baik.

\section{Hambatan Strategi Komunikasi Pemasaran}

Dinas Pariwisata, Kebudayaan, Pemuda dan Olahraga

Pada dasarnya dalam proses penyusunan strategi komunikasi pemasaran Disparbudpora terdapat beberapa faktor pendukung dan penghambat di setiap masingmasing tahapan kegiatan. Akan tetapi penulis akan fokus membahas tentang beberapa faktor penghambat Disparbudpora dalam proses penyusunan strategi komunikasi pemasaran.

Secara umum, faktor penghambat termasuk dalam tahap evaluasi. Evaluasi adalah tahap akhir dalam sebuah penyusunan strategi. Proses evaluasi strategi menghasilkan suatu keputusan atas tingkat keberhasilan suatu pelaksanaan. Keputusan strategis yang salah dapat menimbulkan kerugian besar dan sulit untuk melakukan suatu perbaikan.

Pada tahap ini Disparbudpora melakukan evaluasi terhadap hasil pencapaian strategi komunikasi pemasaran yang telah dilaksanakan. Dari pencapaian suatu pelaksanaan terdapat beberapa faktor penghambat dalam proses evaluasi. Mengenai proses evaluasi objek wisata yang dilakukan oleh Dinas Pariwisata, Kebudayaan, Pemuda dan Olahraga Kabupaten Situbondo, terekam dalam wawancara dengan Drs. Tulus Prijatmadji, sebagai berikut:

"Bentuk evaluasi Disparbudpora dalam setiap kegiatan kita pasti melakukan evaluasi. Selain itu kita selalu memperbaiki kekurangan dari setiap event yang dilaksanakan, mungkin ada kritik maupun saran dari masyarakat terhadap setiap kegiatan yang kurang memuaskan. Hasil dari pelaksanaan strategi Disparbudpora belum sesuai dengan apa yang kami harapkan. Dalam proses pelaksanaan tersebut tentunya setiap kegiatan tidak selalu berjalan dengan lancar, pasti terdapat faktor pendukung dan penghambatnya. Faktor pendukungnya adalah kerja sama antar instansi terkait dan pihak sponsor yang telah mendukung semua kegiatan Disparbudpora. Faktor penghambatnya adalah minimnya anggaran dana yang diberikan oleh pemerintah dan kurangnya kesadaran dari sebagian masyarakat terhadap lingkungan sekitar khususnya pada kawasan objek wisata. Inovasi kedepan untuk menjadikan pariwisata Kabupaten Situbondo menjadi lebih baik adalah kami akan bekerja sama dengan Dirjen Pemasaran Pariwisata dan pihak swasta lainnya dalam mengembangkan objek wisata khususnya di Taman Nasional Baluran. Ada potensi wisata apa lagi selain Padang Savanah Bekol dan Pantai Bama, karena sebenarnya masih banyak lagi potensi wisata di kawasan Taman Nasional Baluran. Untuk itu kami sangat berupaya meningkatkan 
pemasaran semaksimal mungkin" (Wawancara:

Hari Senin, 11 Mei 2015).

Adapun beberapa faktor penghambat dalam proses penyusunan strategi komunikasi pemasaran Disparbudpora adalah sebagai berikut:

1. Hambatan Komunikator

Minimnya komunikator untuk menyampaikan pesan terhadap komunikan/ masyarakat dalam proses penyusunan strategi komunikasi, sebab komunikan yang akan dihadapi adalah masyarakat/wisatawan yang terhitung sangat banyak sehingga bukan hanya Disparbudpora dan Duta Wisata yang berperan sebagai komunikator. Walaupun Disparbudpora telah meningkatkan kualitas media elektronik maupun media cetak untuk menyebar luaskan pesan, akan tetapi tidak semua kalangan masyarakat/wisatawan dapat menggunakan media tersebut. Oleh sebab itu, media dinilai masih kurang efektif dalam menyampaikan pesan untuk memberi efek perubahan pola pikir maupun kesadaran diri akan keikutsertaan peran masyarakat dalam upaya mengembangkan sektor pariwisata Kabupaten Situbondo. Hal ini terbukti pada kurangnya sosialisasi ataupun pendekatan secara persuasif terhadap komunitas-komunitas yang berkecimpung dibidang pariwisata.

\section{Hambatan Pesan}

Disparbudpora dan Duta Wisata selaku komunikator dalam menyampaikan pesan terhadap masyarakat dinilai tidak dapat memberikan layanan informasi secara menyeluruh tentang potensi wisata maupun berbagai macam kegiatan dalam proses penyusunan strategi komunikasi pemasaran, sehingga tidak memberi efek yang signifikan pada komunikan. Hal tersebut dibuktikan dengan kurangnya kesadaran, pola pikir dan keikutsertaan peran masyarakat pada setiap kegiatan yang dilakukan oleh Disparbudpora dalam upaya mengembangkan sektor pariwisata Kabupaten Situbondo.

3. Hambatan Media

Media merupakan alat atau sarana penghubung penyampaian pesan untuk memberikan informasi lebih ke khalayak luas termasuk masyarakat/wisatawan sebagai komunikan. Akan tetapi, media yang digunakan Disparbudpora belum dinilai baik dikarenakan pembaharuan data pada laman website masih kurang. Selain itu, Disparbudpora juga belum mengembangkan media elektronik berupa aplikasi android yang mana aplikasi android banyak digunakan oleh masyarakat/wisatawan sehingga media tersebut berperan sangat penting dalam menyebarluaskan informasi tentang potensi wisata Kabupaten Situbondo. Media cetak Disparbudpora sudah dinilai baik dengan dibuatnya Public Event sebagai sarana penyalur pesan berupa susunan acara dalam sekala satu tahun. Namun Disparbudpora belum memiliki media cetak lain berupa macam-macam potensi wisata yang dapat dikunjungi oleh masyarakat/wisatawan yang berupa brosur wisata. Media pembangunan yang belum terlaksana untuk mengembangkan potensi wisata adalah belum dilakukannya perbaikan jalan/akses 
menuju wisata Savana Bekol maupun Pantai Bama, belum melakukan perbaikan atas rusaknya Mangrove Trail di Pantai Bama, dan kurangnya perhatian terhadap sarana dan prasarana Pantai Tampora oleh Disparbudpora, seperti tidak terdapat papan perhatian maupun pemberitahuan, toilet umum dan berbagai sarana lainnya akibat minimnya dana pemerintah untuk pengembangan sektor pariwisata di Kabupaten Situbondo.

\section{Kesimpulan}

Dari proses pemaparan data dan pembahasan, diperoleh kesimpulan tentang proses strtategi komunikasi pemasaran Dinas Pariwisata, Kebudayaan, Pemuda dan Olahraga dalam upaya mengembangkan pariwisata Kabupaten Situbondo, kesimpulan tersebut diantaranya:

1. Dalam proses menyusun strategi komunikasi pemasaran, Disparbudpora melakukan tahapan dasar yaitu

a. Disparbudpotra melakukan suatu pendataan/inventarisasiasi pada potensi wisata secara menyeluruh dan membuka peluang serta bekerja sama dengan pihak kecamatan maupun masyarakat sebagai pemilik daerah yang mengetahui tentang kondisi daerah tersebut untuk memberi informasi mengenai adanya potensi wisata baru.

b. Dalam melakukan perencanaan, Disparbudpora akan berkoordinasi dengan Satuan Kerja Perangkat Daerah (SKPD), masyarakat, pihak Taman Nasional Baluran dalam melakukan perencanaan pembangunan sarana dan prasarana dalam jangka waktu yang panjang. Disparbudpora juga akan memberi informasi/pesan melalui media yang berupa laman website, Public Event yang disebarkan di beberapa sudut daerah, akan menyediakan brosur untuk disebarluaskan kepada berbagai biro perjalanan/travel, akan bekerja sama minimal dengan salah satu pihak media televisi nasional, akan menunjuk perwakilan Duta Wisata terpilih sebagai salah satu komunikator.

c. Dalam pelaksanaan strategi komunikasi pemasaran Disparbudpora melakukan peningkatan fasilitas sarana dan prasarana, mengadakan berbagai macam kegiatan yang tertera pada Public Event, telah menyediakan media sosial berupa laman website, telah menyebarluaskan brosur kepada biro perjalanan/travel, menjalin kerja sama dengan salah satu pihak media televisi swasta nasional yaitu MNC TV, telah mengirim perwakilan Duta Wisata dalam ajang pemilihan Raka-Raki Jawa Timur.

2. Hambatan yang ditemukan dalam proses penyusunan strategi komunikasi pemasaran adalah minimnya komunikator untuk menyampaikan pesan terhadap komunikan/masyarakat, Disparbudpora dan Duta Wisata selaku komunikator dalam menyampaikan pesan terhadap masyarakat dinilai tidak dapat 
memberikan layanan informasi secara

menyeluruh, pembaharuan data pada laman website masih kurang, belum mengembangkan media elektronik berupa aplikasi android, belum memiliki media cetak lain berupa macam-macam potensi wisata yang berupa brosur wisata, belum dilakukannya perbaikan jalan/akses menuju wisata Savana Bekol maupun Pantai Bama, belum melakukan perbaikan atas rusaknya Mangrove Trail di Pantai Bama, dan kurangnya perhatian terhadap sarana dan prasarana Pantai Tampora oleh Disparbudpora 


\section{DAFTAR PUSTAKA}

Effendy, Onong Uchjana. 2011. Ilmu Komunikasi: Teori dan Praktek.Bandung : PT. Remaja Rosdakarya.

Effendy, Onong Uchjana. 2008. Dinamika Komunikasi.Bandung : PT. Remaja Rosdakarya.

Karyono, H. 1997. Kepariwisataan. Jakarta: PT Gramedia Widiasarana Indonesia.

Moleong, L. 2012. Metodologi Penelitian Kualitatif. Bandung: PT Remaja Rosdakarya.

Moriarty, Sandra. 2011. Adverising. Jakarta: Kencana.

Muljadi, A.J., 2010. Kepariwisataan dan Perjalanan. Jakarta: PT Raja Grafindo Persada.

Sendjaja, S. Djuarsa. 1994. Teori Komunikasi. Jakarta: Universitas Terbuka.

Soekadijo, R.G. 1997. Anatomi Pariwisata. Jakarta. PT Gramedia Pustaka Utama.

Sunarjo, Djoenaesih S. 1995. Himpunan Istilah Komunikasi. Yogyakarta : Liberty.

Suprapto, Tommy. Drs. M.S. 2011. Pengantar Ilmu komunikasi. Yogyakarta: CAPS.

Swastha, Basu dan Irawan. 2001. Manajemen Pemasaran Modern. Yogyakarta: Liberty.

Tjiptono, F. 2002. Strategi Pemasaran. Yogyakarta: Andi.

Tjiptono, Fandy. 2008. Strategi Pemasaran. Yogyakarta: Andi.

Yoeti, Oka A. 1985. Pemasaran Pariwisata. Bandung: Angkasa.

Yulianita, Neni. 2001. Komunikasi Pemasaran. Surabaya: Program Pascasarjana Universitas Dr. Soetomo.

Disparbudpora. 2013. Laporan Akuntabilitas Instansi Pemerintah Disparbudpora Kabupaten Situbondo. Situbondo: Dinas Pariwisata, Kebudayaan, Pemuda dan Olahraga.

Fadhlulloh, Muhammad H. 2014. Strategi Dinas Kebudayan Dan Pariwisata Kabupaten Banyuwangi Untuk Promosi Pariwisata Dalam Perspektif Komunikasi Pemasaran. Skripsi Ilmu Komunikasi. Surabaya: Universitas Islam Negeri Sunan Ampel Surabaya.

http://www.rumahkomunikasi.com [18 April 2015]

http://belajar-komunikasi.blogspot.com [Akses, 18 April 2015].

http://budpar.go.id./filedata/5436 1695-Rankingdevisa.pdf [Akses, 20 April 2015]

http://www.rumahkomunikasi.com/2014/10/strategi-komunikasi-pengertian dan.html [Akses, 20 April 2015]

http://belajar-komunikasi.blogspot.com/2011/02/psikologi-komunikator.html [Akses, 21 April 2015]

http://situbondokab.bps.go.id//Akses, 21 Juni 2015]

http://situbondokab.go.id/2015/01/home.html [Akses, 21 Juni 2015]

http://wisatamu.com/2014/11.html [Akses, 21 Juni 2015]

http://wisatasitubondo.com/2013/12/home.html [Akses, 21 Juni 2015] 